\title{
BRIEF COMMUNICATION LABORATORY DIAGNOSIS OF ACUTE HUMAN PARVOVIRUS B19 INFECTION BY SPECIFIC IgM DETECTION
}

\author{
Jussara P. NASCIMENTO(1,4) , Alicia MISTCHENKO(2) \& Bernard J. COHEN(3)
}

KEYWORDS: Human parvovirus B19; Ig M detection; Diagnosis

The laboratory diagnosis of acute human parvovirus B19 infection was for a long time impaired by the lack of a commercial test to detect specific anti-B19 IgM. Nowadays, there are several commercial tests available. The first available in Latin America was an immunofluorescence assay (IF, Biotrin, Ireland) that is based on Sf9 cells infected with recombinant baculovirus expressing VP1 protein. The work described in this paper evaluated IgM IFA Biotrin (IF-Biotrin), as done in routine hospital conditions, in comparison with $\mu$-capture assays by enzyme immunoassay (MACEIAFIOCRUZ) or radioimmunoassay (MACRIA - CPHL) using native virus antigen.

Seventeen sera collected from children with a variety of clinical presentations and suspected of having acute human parvovirus B19 infection (1995) and fifty four sera from children presenting with exanthematic disease typical of fifth disease (1996) were tested by IF-Biotrin for anti B19 IgM in Hospital de Niños Ricardo Gutiérrez, Buenos Aires.

These sera were then sent to Instituto Biomédico/UFF for confirming the diagnosis by MACEIA-FIOCRUZ. Sera presenting discrepant results were then sent to CPHL-UK, and tested by MACRIA. In addition, 96 sera collected from children in a surveillance programme for exantemathic disease were tested for anti B19 IgM by MACEIA and MACRIA. IgM anti B19 detection by IF-Biotrin was performed as recommended by manufacturer. MACEIA was performed as described ${ }^{3}$ with the following modifications: BrIII antigen was used at a 1/200 dilution and VRD/ 11/B19 monoclonal antibody purified from ascitic fluid was used at a 1/4000 dilution. MACRIA was performed as described ${ }^{2}$.

As seen in TABLE 1, from seventeen sera tested by IFA during 1995, 6 were positive, 2 negative and 9 doubtful. All six positive were negative by MACEIA. Both negative sera were confirmed as negative by MACEIA. Among 9 doubtful, 4 were positive. Fifty-four sera were tested by IFA during 1996. From 35 IFA positive, 9 were negative by MACEIA and from 14 IFA negative, one was positive by MACEIA. Among 5 doubtful only one was positive by MACEIA. All results found by MACEIA were confirmed by MACRIA. In Table 2 are the results found for the 96 sera tested by MACEIA and MACRIA. Overall there was $100 \%$ agreement among negative (sensitivity) and $100 \%$ agreement among positive (specificity) samples including 1 positive Buenos Aires serum from Table 1 and 15 negative sera from the same table.

During the last years, several commercial tests ${ }^{5,6,7}$ for specific anti-B19 IgM have been developed and used to diagnosis acute infection. Although mostly specific and sensitive, these tests can produce false positive and false negative results. Some papers in the literature do not use any method to confirm B 19 infection other than these commercial tests ${ }^{1,4}$. Other techniques like DNA detection by PCR or hybridization (in situ, dot-blot), or even IgM detection using native antigen in a capture assay format should be available as confirmatory test ${ }^{2}$. As a consequence of this practice a large list of distinct pathologies supposed related to human parvovirus B19 as the aetiological agent, has been reported during the last two years (1996-1997). The results we show in this paper stress the necessity of a more rigorous laboratory diagnosis confirmation when attempting to correlate B19 infection and new pathologies as, even with a test considered to have a good performance as Biotrin IFA ${ }^{7}$ can cause false positive results in routine conditions.

Our results suggest that a subjective test, like IFA, can produce false positive and false negative results when performed under routine conditions. Confirmation by other techniques for anti B19 IgM or the presence of viral genome is needed, especially when the observed clinical symptoms are rarely associated with B19 infection.

(1) Instituto Biomédico/UFF-Brasil,

(2) Hospital de Niños Ricardo Gutiérrez/BA-Argentina,

(3) Virus Reference Division/CPHL-UK

(4) Instituto Oswaldo Cruz/FIOCRUZ-Brasil.

Correspondence to: Jussara Pereira do Nascimento. Departamento de Microbiologia e Parasitologia, Instituto Biomédico, UFF. Rua Hernani Mello 101. 24210-000 Niterói, RJ, Brasil 
NASCIMENTO, J.P.; MISTCHENKO, A. \& COHEN, B.J. - Laboratory diagnosis of acute human parvovirus B19 infection by specific IgM detection. Rev. Inst. Med. trop. S. Paulo, 40 (4): 265-266, 1998.

TABLE 1

Comparison of results by IF Biotrin and MACEIA

\begin{tabular}{|c|c|c|c|c|c|c|c|}
\hline \multirow{3}{*}{ IF Biotrin } & \multicolumn{6}{|c|}{ YEAR } & \multirow[b]{3}{*}{ Total } \\
\hline & \multicolumn{3}{|c|}{1995} & \multicolumn{3}{|c|}{1996} & \\
\hline & $\begin{array}{l}\text { MACEIA } \\
\text { Positive }\end{array}$ & $\begin{array}{l}\text { MACEIA } \\
\text { Negative }\end{array}$ & Sub Total & $\begin{array}{l}\text { MACEIA } \\
\text { Positive }\end{array}$ & $\begin{array}{l}\text { MACEIA } \\
\text { Negative }\end{array}$ & Sub Total & \\
\hline Positive & 00 & 06 & 06 & 26 & 09 & 35 & 41 \\
\hline Negative & 00 & 02 & 02 & 01 & 13 & 14 & 16 \\
\hline Doubtful & 04 & 05 & 09 & 01 & 04 & 05 & 14 \\
\hline Total & 04 & 13 & 17 & 28 & 26 & 54 & 71 \\
\hline
\end{tabular}

TABLE 2

Comparison of results found by MACRIA and MACEIA

\begin{tabular}{ccc}
\hline MACRIA/CPHL & \multicolumn{2}{c}{ MACEIA/FIOCRUZ } \\
\cline { 2 - 3 } Positive & 02 & Negative \\
Negative & 00 & 00 \\
Total & 02 & 94 \\
\hline
\end{tabular}

\section{REFERENCES}

1. CHAMBERS, L.A. \& RAUCK, A.M. - Acute transient hemolytic anemia with a positive Donath - Landsteiner test following parvovirus B19 infection. J. Pediat. Hematol. Oncol., 18: 178-181, 1996.

2. COHEN, B.J. - Detection of parvovirus B19-specific IgM by antibody capture radioimmunoassay. J. virol. Meth., 66: 1-4, 1997.

3. CUBEL, R.C.N.; ALFERES, A.C.R.; COHEN, B.J. \& NASCIMENTO, J.P. Application to immunoglobulin $M$ capture hemadherence assays to hemagglutination of monkey erythrocytes by native and recombinant human parvovirus B19 antigens. J. clin. Microbiol., 32: 1997-1999, 1994.

4. ERGAS, D.; RESNITZK, P. \& BERREBI, A. - Pure red blood cell aplasia associated with Parvovirus B19 infection in large granular lymphocyte leukemia. Blood, 87: 3523-3524, 1996.

5. JENSEN, I.P. \& VESTERGAARD, B.F. - Assessment of the specificity of a commercial human parvovirus B19 IgM assay. Clin. Diag. Virol., 7: 133137, 1997.

6. SCHWARZ, T.F.; JAGER, G. \& GILCH, S. - Comparison of seven commercial tests for the detection of Parvovirus B19-specific IgM. Zbl. Bakt., 285: $525-530,1997$.

7. SLOOTS, T. \& DEVINE, P.L. - Evaluation of four commercial enzyme immunoassays for detection of immunoglobulin $M$ antibodies to human Parvovirus B19. Europ. J. clin. Microbiol. infect. Dis., 15: 758-761, 1996.

Received: 15 June 1998

Accepted: 21 July 1998 